LINGUACULTURE 1, 2018

\title{
CHANGES OF FRAMES - A COMPARATIVE ANALYSIS
}

\author{
GABRIELA CHEFNEUX* \\ Transilvania University of Braşov, Romania
}

\begin{abstract}
The paper starts from the assumption that organizational culture can be defined as the type of behavior, mainly considered in interactional terms, which is deemed acceptable by the employees (Hofstede 45). By analyzing frames, footing and their changes, the paper aims to compare the culture in two companies-a joint company (Romanian Belgium where English is used as the language of communication) and a Romanian one. The data used for the analysis come from two face-to-face meetings in these two companies.
\end{abstract}

Keywords: organizational culture; institutional talk; frame; footing; changes of frames and footing.

\section{INTRODUCTION}

Hofstede (45) defines organizational culture as the sum of the employees' ideologies, beliefs and practice, which influence their behavior at the workplace and which they consider acceptable. Institutional talk, one of the forms by means of which the culture is expressed, is characterized by its orientation towards a specific aim (to carry out professional tasks), by constraints in terms of what can be said (topics) or done (speech acts), while the interaction is characterized by a system of pre-allocating interventions in communication. By comparing two meetings in two different companies (a Romanian and a joint one), the paper aims to identify cultural similarities and differences between these two companies.

\footnotetext{
$\overline{\text { *chefneuxgabriela@yahoo.co.uk }}$
} 


\section{THEORETICAL FRAMEWORK}

\section{FRAME}

The concept of frame has been studied by a variety of disciplines such as sociology, anthropology, cognitive psychology and semantics (Tanen, Wallat).

Goffman (247) states that the concept of frame is closely connected to the expectations people have as knowledge is structured in terms of scripts, schemata and prototypes; he defines a primary framework as a frame that turns a possibly meaningless aspect of a scene into a meaningful one, thus structuring the activity people are involved in and helping them to interpret it. Similarly, Straehle (213) compares frames to labels that help interlocutors identify what they are doing.

Schiffrin defines frames as "structures of knowledge about situation, actions and actors" (233), which inform our expectation in terms of what is, will and has happened. Tannen describes them as "the way of showing how we mean what we say or do and figuring out how others mean what they say or do" ("What's in a Frame?" 43) and states that they involve expectations in terms of people, objects, events, and ways to interact.

Frames are interactive and dynamic as they change according to what is said or done; they shift and transform while being checked against our current patterns of knowledge (Goffman 349). Tannen states that "the framing that is going on at any moment is part of what establishes the frame for what goes on next and is partly created by the framing that went before" (That's Not What I Meant 78). Frames are usually conveyed by means of metamessages, linguistic and nonlinguistic cues - for example teasing may be marked by laughter, prosody, specific utterances (Tannen, That's Not What I Meant 23). During interaction, several frames may operate and sometimes they are conflicting (Tannen, Wallat 59); interlocutors may choose to accept or resist them (Tannen, That's Not What I Meant 77).

Another feature is indirectness; the power of frames is that they do their work off the record: "they let us mean what we say without saying what we mean in so many words, they allow us to renege" (Tannen, That's Not What I Meant 71). They play an extremely important part in interpreting correctly what is actually being said and what the speaker's attitude is; their misinterpretation can cause conflict, misunderstanding or embarrassment.

Mismatches between the way in which frames are understood are linguistically reflected in a variety of ways-omission, repetition, false starts, backtrack (a disruption in the narrative flow), hedges, negatives, contrastive connectives, modals, inexact statements, generalization, inferences interpretation, evaluation. Tannen also identifies indirect ways of signaling 
framing-such as "pitch, tone of voice, intonation, facial expression" (That's Not What I Meant 63), lexical choices.

This paper uses Straehle's definition of frames- "labels used to identify what is going on in a conversation" (213).

Hoyle (129-37) identifies several frame levels-outermost, outer and inner. In her article, which analyses a game between two boys, she describes the game as the outermost frame, sports casting as the outer one, and participant's speaking as themselves or sportscasters as inner frames.

Schiffrin (231) differentiates between-frame activities which mark the shift between a main frame to the next and out of frame activities which have no connection with the previous or following frame. Finally, conflation can be defined as the amalgamation of at least two frames.

\section{FOOTING}

Footing is a concept that is closely related to frames and which reflects the type of activity the interlocutors are engaged in and their relations during it (Goffman 349); Hoyle defines footing as "the way in which framing is accomplished in verbal interaction" (115).

Goffman describes it as "another way of talking about a change of frame for events" and as a "change in the alignment we take up to ourselves and the others present as expressed in the way we manage the production or reception of an utterance" (128). Footing indicates the way in which the participants frame events and negotiate their relationship and reflects the way in which participants position themselves both to their utterances and to each other (Schiffrin 233). As such, footing plays a major part in projecting a speaker's identity, as the footing adopted reflects a particular social role and status (Schiffrin 233). Footing is a way in which speakers present themselves, and is usually determined by the speaker's selecting "the least self-threatening position” (Levinson 157).

Like frames, footing constantly changes and evolves: "The framing that is going on at any moment is part of what establishes the frame for what goes on next, and is partly created by the framing that went before. The footing we establish at any moment is occasioned by the footing that was established the moment before-and the year before". (Tannen, That's Not What I Meant 78).Unlike frames, footing is only linguistically expressed: "linguistics provides us with cues and markers through which (...) footings become manifest” (Goffman 16). Changes in frames may also trigger changes in footing. The footing or participants' alignment indicates the interactants' relationships of power and solidarity and their affective stances (Schiffrin 233) and it identifies the relationship between speakers. Footing can be negotiated and, like frames, it has a dynamic character, being 
changed and "continually checked against experience and revised" (Tannen, Wallat 49). It can sometimes be misinterpreted, thus causing embarrasment or even conflict: "When cultural differences are at play... the footing intended and the one perceived may differ" (Tannen, That's Not What I Meant 70).

\section{DATA PRESENTATION}

The first set of data was collected in a joint company, a Belgium Romanian one; it is an IT company with the main office in Belgium and a subsidiary in Romania, where Romanian employees work. The team in Romania has a team leader who is Belgian; they communicate by means of phone conferences and face-to-face meetings. The data analysed below represent the transcripts of such a face-to-face meeting which brings together 16 participants-F1 is the Belgian team leader, R1-R15 the Romanian employees. The aim of the meeting is to decide on administrative issues. (For transcribing conventions see Appendix 1)

The second set of data was collected in a Romanian company which sells bathroom items. The data represent the transcript of a meeting organized by the sales and marketing department. It brings together 7 participants - Carmen, the manager of the sales and marketing departments, and 6 male managers: Adi, Dorin, Costi, Ionuţ and Vasile, all regional sales managers, and Tibor, financial manager. The aim of the meeting is to analyse the sales activity of the company. (For transcribing conventions see Appendix 2)

In both cases the outermost frame is the institution and the outer one the meeting. Below are analyzed some of the inner frames, the purpose being to identify similarities and differences between the organizational culture in the two companies.

\section{ANALYSIS}

\section{OUT OF FRAME}

\section{E.g. 1 The Romanian company}

The example presents Carmen who is analyzing the sales results obtained the previous year and comments on the figures-the out of frame stage is her checking whether everybody can see the figures clearly:

Carmen: în rest mai mult sau mai puţin se apropie de...patru \# nouăşunu la sută de cinci nouăşdoi la sută \#\# 
la :: ferestre vedeţi toată lumea indicatorii $\downarrow$ da? (Gheorghe, Măda, Săftoiu 132)

Carmen: for the rest, they come more or less closer to... four\# to four nine one percent to five nine two percent\#\# for... windows you all see the indicators $\downarrow$ yes?

The change from the official presentation of the figures to the more personal check of whether the participants can see them is interpreted as an out of frame situation, which also affects Carmen's footing towards the participants-from the person in charge to a more caring person. Alternatively, another interpretation could be that Carmen wants to make sure that what she says is easily understood by the participants.

\section{E.g. 2 The joint company}

After the meeting starts, one of the Romanian participants reminds the team leader of the recorder, which classifies the situation as an out of frame one:

R16: we will start [unclear word] from here, they will do something on that.

F1: yeap

?: $\quad$ sure.

R2: F1 don't forget your recorder

R12: sure. [laughter]

F1: they uhm (.) may still be quite busy there, but uhm (2) only uhm

R2: this is what I expect (Coposescu, Chefneux 108)

The discussion about future planning is interrupted by R2 who reminds F1 that he should turn on the recorder. This out of frame generates laughter but the topic is not pursued by the participants.

\section{FROM PROFESSIONAL TO JOKING}

\section{E.g. 3 The Romanian company}

The example below illustrates how Carmen changes the frame from praise to criticism, which she softens by smiling and joking. She is presenting the sales figures obtained during the current and previous years; she begins by stating that the situation is better but she immediately adds that it would have been catastrophical for things to be different, as the company would not have existed any more. She mitigates her remarks by smiling and by resorting to indirectness: 
Carmen: comparativ cu douămii cinci $\downarrow$ situaţia stă mai bine $\downarrow$ normal $\downarrow$ dar ar fi fost o catastrofă să nu stea mai bine $\downarrow<@$ pentru că ar fi însemnat că $>$ nu avea sens să ne mai întîlnim în douămiişase. (Gheorghe, Măda, Săftoiu 133)

Carmen: as compared to two thousand five $\downarrow$ the situation is better $\downarrow$ naturally $\downarrow$ but it would have been a catastrophe not to be better $\downarrow<@$ because that would have meant that $>$ meeting in two thousand six would have been useless.

This negative situation is acknowledged by the participants through silence, none of them interrupting or adding anything.

\section{E.g. 4 The joint company}

The Belgian team leader also resorts to humour to deal with difficult situation.

During the discussion about connections, the Romanian participants indicate that they favor having shared accounts while F1 supports individual accounts.

The discussion is quite lengthy and at one point, F1 changes the frame from argumentation and negotiation to joking:

F1: so you run XXX here?

(2) ok so we know why we are bad with connections.

[laughter]. (Coposescu, Chefneux 115)

Later, towards the end of the discussion about this topic, F1 jokes again:

F1: $\quad$ some problems

there's many problems that only occur on one type of Unix computer. especially IBM, but also especially HP and also especially XXX [laughter](5) so instead of investing money in getting Unix machines here I would prefer to invest money in improving our internet connection. (Coposescu, Chefneux 118 - 19)

F1 marks the joke by repeating "especially", which indicates the high number of problems and signals the return to the professional frame by the use of "so". 


\section{FROM PROFESSIONAL TO PERSONAL}

\section{E.g. 5 The Romanian company}

At the beginning of the meeting Carmen asks the other sales managers what they discussed before she arrived and next she introduces a new colleague, Vasile. She alternates the frames from professional-introduction-to personal, probably in order to make the new employee feel more comfortable:

Carmen: pe noul coleg l-aţi ::\# cunoscut $\uparrow$ da?

Adi: [da: da $\downarrow$ da $\downarrow$ am făcut cunoştinţă

Carmen: știi CU CINE te duci la plimbare.

Vasile: $a \downarrow$ nu ne-am gândit încă cu

Carmen: (către [prenume] noul coleg)) tu eşti tare trist astăzi\# ă?

Vasile: ((neagă mormăind)) m:: $\downarrow$ m::

Carmen: nu个 am crezut că eşti trist\#\# ((către [prenume] $\downarrow$ care tocmai a intrat pe uşă)) servus. \#

((către toţi)) hai că facem o \# începem...

... inspiră adânc (Gheorghe, Măda, Săftoiu130-31)

Carmen: the new colleagues you have ::\# met $\uparrow$ right?

Adi: [yes: yes $\downarrow$ yes $\downarrow$ we have met

Carmen: you know WITH WHOM you go driving.

Vasile: well $\downarrow$ I haven’t thought yet with

Carmen: (to [first name] new colleague)) you are very sad today\# uhm?

Vasile: ((denies mumbling)) uhm:: $\downarrow$ uhm::

Carmen: no $\uparrow$ I thought you were sad\#\# ((to[first name] $\downarrow$ who just entered the room)) hi. \#

((to all)) let's have a \# we're starting

... takes a deep breath

Carmen makes sure that everybody has met the new colleague and then she switches to a more personal discussion by asking this new team member whether he now knows with whom he is going for a drive-they are all sales managers and travel a lot.Vasile is taken aback as indicated by the pause.

Carmen continues this frame by teasing him-"you are very sad today", and again Vasile tries to find an answer, and mumbles. The explanation could be that Vasile is not accustomed to his new manager and therefore is not prepared for these personal exchanges.

The end of this personal discussion is signalled by Carmen when she turns her attention to a sales manager who has just entered and whom she greets, after which she addresses everybody by announcing the start of the meeting. 
The next stage, the presentation of the sales situation, is marked by Carmen's taking a deep breath.

During this stage of the meeting Carmen is the only one who triggers changes of frame from professional to personal, which indicates her position of power.

\section{E.g. 6 The joint company}

In the joint company the situation is rather different. It is mainly the Romanian team members who trigger changes of frames from professional to personal. The explanation could be that the company culture is more relaxed and, maybe, that the Romanian team members want to establish a closer relationship with the team leader.

The example below illustrates this remark. The topic is working on a laptop or on a desktop computer. The team leader tells the team that they can choose between the two and the employees discuss the advantages and disadvantages with R8 introducing a personal topi related to his health.

R1: //it's a pleasure to work on a laptop.

R10: it's not powerful enough.

R8: we're talking about the screen, the position that you sit at the table and look at it.

F1: yeah.

R8: for me, at least I have some back problem because I work on $\mathrm{a}=$

R11: =//another

R8: //laptop on the desk

R11: another question. (Coposescu, Chefneux 123)

R8 introduces the back problem with "for me", which announces a personal topic, and mitigates it with "at least" and with an adverbial clause of reason, as he tries to explain the source of his aches. However, this personal frame is disregarded by the others; R8 tries to continue the topic "laptop on the desk" but is interrupted for the second time by R11 who raises a new topic.

R8's intervention can be interpreted as an indication of the friendly atmosphere that exists in the company, with Romanian team members feeling at ease to raise a variety of topics, related to other areas besides the professional one. 


\section{E.g. 7 The joint company}

The example below illustrates the change of frame from professional to personal; it is a discussion involving all the participants in the meeting, during which one of theRomanians triggers the change of frame, which is uptaken by several others. The topic is the Romanian employees' trip to the Belgian headquarters.

R10: =L sent us the planning hour by hour, should we

R13: hour by hour?

[laughter]

F1: no.

R11: go to XXX, see what is going on and (.) that's all.

R1: I think everybody received the planning.

R4: there there was an excel chart about (.) meetings and

R1: //so why why this

R10: //there are some there are some big points like uhm for example, Wednesday we have uhm (.) a party.

[laughter]

R10: I don't know what to

R7: and you said (towards R1) they won't party laughter - R10 and R12 sidetalk)

F1: so why there's difference [overlapping talk]

[...]

F1: //so how come there's a difference in inerpretation between you and R13?

R13: there's difference beteen R10 and us. [laughter]

R12: it was an excel sheet (.) it was sent to us in an attachment so maybe R10: I didn't see it.

(2)

R10: maybe I didn't receive it. I don't know.

F1: ok, can you //verify?

R10: //yes I will. (Coposescu, Chefneux 111-12)

This stage in the meeting involves discussions about the Romanian team members going to the main office in Belgium. R10 states that the programme they received is one that describes the activities hour by hourthis is actually the moment when the professional discussion changes to a personal one, as the strict schedule makes the Romanians laugh; R10 and R2 sidetalk, while the others continue the discussion about the party with jokes, with F1 trying unsuccessfully to bring the discussion back to professional issues. When F1 says that there is a difference in interpretation, R13 continues the personal sequence-“there's a difference between R1 and us", 
which causes again laughter. Finally, F1 manages to bring the discussion back on track by asking one of the members to check the mail ("F1: ok, can you verify").

This frame change is marked by laughter, sidetalking and several jokes made by the Romanian participants.

The footing in this sequence is changed by the Romanian participants, who are no longer employees listening and answering their leader's questions, but colleagues and Romanians joking about cultural and personal differences.

Unlike Carmen, F1 never changes frames from professional to personal. He usually waits for the other to finish and brings them "to order" by using words such as "so", "OK”.

\section{FROM PROFESSIONAL TO IMAGINARY}

\section{E.g. 8 The joint company}

Another frame change is from professional to imaginary, a situation identified only in the joint company.

R11: who's going to come?

(1)

F1: uhm An and R. St is not coming. J.

R11: because I'm leaving on Monday.

F1: yeap. so that's why St is not going to join because you're not here.

R11: I'll be in Bahamas.

[laughter]

R8: you will be in Bahamas.

[laughter] (Coposescu, Chefneux 112)

The discussion is about who will go to the headquarters and F1 gives the names of two people who will not go. R11 explains why he is not going by resorting to a far-fetched explanation-“I'll be in the Bahamas"-an utterance that causes laughter. As it is quite unexpected, $\mathrm{R} 8$ repeats it after which the professional discussion continues.

\section{CONFLATION - PROFESSIONAL AND PERSONAL}

\section{E.g. 9 The Romanian company}

During her presentation, Carmen resorts to a mixture of professional and personal styles; she objectively discusses last year's sales results which she supports with figures but also introduces her personal opinions in an 
informal way-the aim being probably to show her coleagues that she forecasts well and that she is close to them.

Carmen: da $\downarrow$ şi la ferestre ştii că e pe aproape $\downarrow$ da $\downarrow$ destul de aproape\# ceea ce m-a suprins în mod plăcut sunt accesoriile $\downarrow$ unde într-adevăr nu degeaba am bătut noi atîta monedă cu ele pentru că:: uite acuma se şi vede că\# se vînd şi culmea se vînd tocmai acolo unde [prenune] spunea că se vînd perdeluţe $\downarrow$ uite că se vînd şi perdeluţe de la [nume] $\downarrow$ da $\uparrow$ la accesorii avem osutăpaişpe la sută. (Gheorghe, Măda, Săftoiu133)

Carmen: yes $\downarrow$ and with the windows you know it's close $\downarrow$ yes $\downarrow$ pretty close\# what pleasantly surprised me are the accessories $\downarrow$ where indeed not in vain have we insisted on because:: look now it can be seen that\# they sell and moreover they sell precisely where [first name] said curtains sell $\downarrow$ look curtains also sell from [first name] $\downarrow$ yes $\uparrow$ with accessories we have a hundred fourteen per cent.

Carmen expresses her personal opinion marking it invarious ways:"what pleasantly suprised me", "not in vain have we insisted on ".

\section{E.g. 10 The joint company}

There is also conflation between professional and personal remarks when the team discusses the future activity of one of the team members who is not present.

R8: I guess in our particular case RX has a lot more time this uhm for this development stage, to do some specifications, watch out for the others how they are going

F1: yeap

R8: I think (.) he's in his soul surprised a bit about this,

F1: $\quad$ that he has more time available.

R8: yes. I mean he does not have too much development tasks, he only has some management and so he has a lot of time for organization (.) of tasks to (.) take care of us, to do the job properly.

F1: $\quad$ mhm. it sound good. that was necessary.

R8: so, he was a little bit relaxed right now about this and (.) he said he'd do more specifications better than descriptions about this.

R1: so that problem wasn’t for XXX or was. (Coposescu, Chefneux109)

The discussion is about RX who has a new position which involves writing specifications. R8 starts it alternating from a professional to a personal frame; he adopts a tentative position as indicated by "I guess in our particular case” but then moves deeper into the personal frame-"I think he's 
in his soul surprised a bit about this". He repeats "I think", he pauses, and use the mitigator "a bit".

F1 tries to steer the discussion to a more professional level by rephrasing R8's words-"'he has more time available", trying to shift R8's footing to the professional one. R8 acknowledges F1's position -"Yes. I mean" - and rephrases his idea in more professional terms: "development tasks," "organization of tasks", "do the job properly", which he combines with more personal ones such as "take care of us", thus continuing the personal frame. F1 summarizes again the idea by stating "it sounds good" and "this was the necessary thing to do", to which R8 replies again in a more personal way "he was a bit relaxed right now about this" -choosing the mitigator "a bit" and he concludes by quoting RX: "he said he'd do more specifications better than descriptions about this".

This exchange indicates that R8 adopts a personal footing both towards the team leader and toward his colleague RX, while F1 continues his professional footing.

\section{SMALLER FRAMES}

\section{E.g. 11 The Romanian company}

Carmen changes from instructions to explanations, evaluations, and descriptions.

Carmen: ia să-ţi notezi lucrul ăsta [prenume] şi să vedem dacă chiar şi poate poţi să afli cam cîte vinde din celelalte $\downarrow$ să ne facem o idee $\downarrow$ avînd şi celelalte scări\#. bine $\downarrow$ în piaţă s-a mai creat o idee clară că în /supermarcheturile/ astea se vînd produse de calitate proastă $\downarrow$ chiar dacă nu e aşa:: idea asta este $\downarrow$ le=am zis şi la gresie $\downarrow$ și faianţă $\downarrow$ şi la scări $\downarrow$ deci lumea deja merge şi\#\# nu ştiu primii douăzeci de /dilări/ vînd peste cinşcinci la sută şi aici avem situaţia:: jumătate din /dilării/ noştri nu vînd scări\# deci o situaţie ŞI mai gravă dacă putem să numim gravă decît la ferestre. (Gheorghe, Măda, Săftoiu136-37)

Carmen: put down this [first name] and see if we even and maybe can find how many of the others they sell $\downarrow$ to have an idea $\downarrow$ having the other ladders\#. OK $\downarrow$ on the market there is a clear idea that in these supermarkets they sell low quality goods $\downarrow$ even if it is not like this:: this idea is $\downarrow$ I told them at the floor tiles $\downarrow$ and stoneware tiles too $\downarrow$ and the ladders too $\downarrow$ so people already go and \#\# I don't know the first twenty dealers sell over fifty five percent and here is the situation:: half of our dealers do not sell ladders\# so a situation even MORE serious if we can call it serious than with windows.

The first small frame is the instruction she gives to one of the sales manager "put this down, [first name] and see if we even and maybe you can 
find about how many of the others he sells" -a sentence which is not very coherent, maybe because she wants to say too many things at once.

Next Carmen expresses her opinion of the market situation ("OK on the market there is a clear idea that in these supermarkets they sell low quality goods even if it is not like this"); she moves from instructing to evaluating by saying "OK", which is preceded by a pause. Next she moves from evaluation to presenting the sales situation ("I don't know the first twenty dealers sell over fifty five percent and here is the situation”), a transition indicated by a longer pause and by "I don't know".

\section{E.g. 12. The joint company}

The overall frame, that of the meeting, can be further broken down into smaller frames, such as giving instructions, explaining, asking for information, providing reasons, offering solutions, etc.

The example below illustrates such a situation-F1 is trying to persuade the team members to choose a shared account rather than individual ones, which, in his opinion, are difficult to maintain.

In order to reach a decision, the team discusses it; the members seem to favour individual accounts, and express their position in a variety of ways. During this part of the meeting, F1 brings arguments in favor of his position by resorting to a variety of smaller frames.The first one is describing-F1 answers R1's question ("why is so hard to maintain some accounts"), by listing the operations involved in it:

F1: uhm you have to know Unix pretty much to: uhm know what you're doing so: (.) to (.) have an account decently working you have to set up your cornshell, you have to have a login script that sets everything correctly (Coposescu, Chefneux 114)

In his reply F1 pauses quite frequently, uses "so", and resorts to adverbials of the type "decently" and "correctly", which are apparently opposed to the setting up of individual accounts.

When the Romanian team members press the issue-R2 and R1 are actually overlapping when asking F1 further questions about these accountsF1 resorts to explanations based on experience.

F1: so uhm it is_possible to create common settings, but so far (.) it is just proven to be very difficult to get that really done.

R1: aha (Coposescu, Chefneux 114) 
F1 phrases his explanation by selecting words that present individual accounts as difficult to maintain and the shared account as a better solution, as indicated by his choice of words:"very difficult", "it is possible", "really done". He seems to persuade R1, who drops the topic.

F1 further suggests a compromise-a large shared account in which the team members could have individual ones for few operations, a solution apparently favoured by the Romanian team members.

F1: uhm we could also try to go

that everybody just requesting Unix account, and then we try to isolate the (.) common settings from the $\mathrm{XXX}$ account, put that in a common script so that everybody has to do only a few things on his account and then everything will be uhm shared.(2) we can try to do that as well. (3) (Coposescu, Chefneux 114)

F1 adopts a variety of footings: a professional who knows his subject, a logical and reasonable person, a manager who wants to accommodate the team members. However, during the last stage of the discussion he appears as an assertive decision maker who allows the team members a limited choice:

F1: =well either a shared account or a (2) supporting two solutions I'm not sure that makes sense. so if you want a shared account then you have to become a good mates with somebody and say can I use your account. so either we use everybody's shared account and then i support it, uhm or we say everybody has a has his own account, but then I'm not gonna support a shared account and stand with your own local interaction. (Coposescu, Chefneux 114 )

His decision points to a compromise-the team members have to choose either a shared or an individual account - as both solutions do not make sense to him.

So, these small frames can be considered part of a negotiation where the two sides adopt different positions-the Romanian team members favor a different choice and challenge the team leader while $\mathrm{F} 1$ presents himself as a negotiator, a logical and experienced person and an assertive manager. The misunderstanding here could be that the Romanian team members do not understand from the beginning F1's position or, alternatively, that they do not agree with it and challenge their manager in an indirect way. 


\section{FOOTING}

In both companies, the most frequent change of footing is from professional to personal; it is mostly triggered by the employees in the joint company and by the manager in the Romanian one.

The managers in both companies are quite flexible but also make their position clear.

\section{E.g. 13. The Romanian company}

There are several instances when Carmen disregards the contribution of one of the sales manager:

Carmen: avem un /dilăr/ care vinde\# douăzeci la sută

Adi: dar are în toată țara magazine ca noi

Carmen: deci asta ne arată două lucruri. (Gheorghe, Măda, Săftoiu135)

Carmen: we have a dealer who sells\# twenty percent

Adi: but he has shops all over the country as we do

Carmen: so this shows us two things.

Carmen continues her presentation, using "so", in order to indicate that she does not want to be interrupted. F1 uses "so" when he wants to put the discussion back on track.

The use of humour also changes the footing from professional to personal.

When Carmen jokes, the sales team members add to what she has already said, thus uptaking the humorous mood. In the joint company, it is always the Romanians who start the humorous frames with the Belgian team leader trying to keep the discussion on track and joking only after he has made his point.

\section{E.g. 14. The joint company}

There is a particular instance of footing that appears only in the joint company, namely the team members attacking indirectly the team leader by questioning his resolutions, which they do in several ways: they return to the decision that was already taken, they make comments in a humorous way, or challenge the leader is a more direct way, as the example below indicates:

R11: uhm not a month. it's three weeks. I spoke with D and he said ok, not less than one week and not more than one month [laughter] we agreed that ok three weeks it’s enough (.) 
F1: yeap.

R11: it's ok.

F1: so then you'll have a lot of holidays to come in two months.

[small laughter]

R11: it depends on how you see it.

(3)

F1: uhm (.) ok, so that's all scheduled. (Coposescu, Chefneux 111)

R11 and F1 discuss holidays and while F1 expresses his belief that R11 has a lot of holidays. R11 challenges him- "it depends on how you see it". This challenge is acknowledged by F1, who pauses and then concludes the discussion about the arrangements for the team to visit the headquarters. The frame changes are linguistically marked by "I think", "ok", umhs, pauses and "so".

There are no such cases in the Romanian company, where employees express their agreement with the manager is a more or less formal manner.

\section{E.g. 15. The Romanian company}

Carmen is analyzing the sales results per regions when Adi interrupts her and thus changes his footing from a listener and passive employee who is merely listening to his boss to an active participant who adds to what the manager has just said. His comment indicates that he wants to emphasise his colleague's good results.

Carmen acknowledges Adi's interruption by "yes" and then continues her comments:

Carmen: dar e foarte bună la $<@$ toate $>$ de fapt $\downarrow<$ așa că $>$ putem spune că e o situație bună

Adi: da $\downarrow$ mai ales la folie

Carmen: da $\downarrow$ şi la ferestre. (Gheorghe, Măda, Săftoiu133)

Carmen: but it is very good $<$ with everything $>$ actually $\downarrow<$ so $>$ we can say it is a good situation

Adi: yes $\downarrow$ particularly with foil

Carmen: yes $\downarrow$ and with windows

The more personal footing is more frequently adopted by the Romanians in the joint company and by the manager in the Romanian company. The managerial footing is more obvious in the Romanian company, where Carmen sometimes chooses to disregard the team's intervention. Actually, during the entire meeting in the Romanian company, there is only one team member who speaks, the others keeping quiet. 


\section{CONCLUSIONS}

In both companies the same types of frame changes can be noticed-from professional to personal and from professional to joking. The difference lies in the frequency, both types being more frequent in the joint company.

Another difference is the person who triggers the frame change-the joking sequences are started by the manager in the Romanian company and by the Romanian employees in the joint one, again with a higher frequency in the joint company.

In both companies there are out of frames and conflation instances with one exception-the imaginary frame identifiedonly in the joint company.

The footing is also slightly different; in the Romanian company Carmen is the one that changes it; she shifts from being a manager who makes decisions and evaluates to becoming closer to the employees and making personal comments.

In the joint company the Belgian team leader adopts for the most part of the meeting a professional footing, with very few changes to joking but usually following the humorous sequences initiated by the Romanian employees rather than initiating them himself.

The Romanian employees in the joint company also adopt more footings than in the Romanian one, namely, close colleagues, Romanians with a different culture from that of the Belgian team leader, indirect challengers and employees closer to the team leader. In the Romanian company the footings are fewer-mainly employees and colleagues.

Both managers try to make sure that there is a good working atmosphere, but with slightly different styles, more formal in the Romanian company and more informal in the joint one.

\section{Works Cited}

Coposescu, Liliana and Gabriela Chefneux, eds. Institutional Talk and Intercultural Communication in Multinational Companies: Corpus of Spoken Interaction in English. Braşov: Editura Universității Transilvania din Braşov, 2008. Print.

Gheorghe, Mihaela, Stanca Măda and Răzvan Săftoiu, eds. Comunicarea la locul de muncă.Corpus de interacțiune verbală in mediul profesional. Braşov: Editura Universității Transilvania din Brașov, 2009. Print.

Goffman, Erving. Frame Analysis-An Essay on the Organization of Experience. Boston: Northern University Press, 1974. Print.

Hofstede, Gert, Jan. Cultures and Organizatios: Software of the Mind. New York: McGraw-Hill, 1997. Print.

Hoyle, Susan, M. "Participation Frameworks in Sportscasting Play: Imaginary and Literal Footings". Framing in Discourse. Ed. Deborah Tannen. New York: Oxford University Press, 1993. 114-145. Print. 
Levinson, Stephen. "Putting Linguistics on a Proper Footing: Explorations of Goffman's Concepts of Participation”. Erving Goffman Exploring the Interaction Order. Eds. Paul Drew and Anthony Wotton. Cambridge: Cambridge Polity Press, 1998. 161-227. Print.

Schiffrin, Deborah. "Speaking for Another in Sociolinguistic Interviews: Alignmentas, Identities and Frames". Framing in Discourse. Ed. Deborah Tannen. New York: Oxford University Press, 1993. 231-262. Print.

Straehle, Carolyn."'Samuel'. 'Yes, dear?' Teasing and Conversational Rapport”. Framing in Discourse. Ed. Deborah Tannen New York: Oxford University Press, 1993. 210-230. Print.

Tannen, Deborah. "What's in a Frame? Surface Evidence for Underlying Expectations “. Framing in Discourse. Ed. Deborah Tannen. New York: Oxford University Press, 1993. 14-56. Print.

Tannen, Deborah. That's Not What I Mean. London: Virago Press. 1998. Print.

Tannen, Deborah and Cynthia Wallat. "Interactive Frames and Knowledge Schemas in Interaction; Examples from a Medical Examination/Iinterview”. Framing in Discourse. Ed. Deborah Tannen. New York: Oxford University Press, 1993. 5776. Print.

\section{Appendix 1}

Symbol
Arabic numerals
[ ]
[work]
?
//
[unclear]
XXX

\section{Appendix 2}

Intonation:

$\downarrow$ falling intonation

$\uparrow$ rising intonation

\# pause

$<$ @ $>$ laughter simultaneous with speaking

$<\mathrm{z}>\quad$ smile simultaneous with speaking

$<$ MARC $>$ words pronounced slower

$<\mathrm{r}>$ fast speech rate. 